\title{
Resistance of Castanea Clones to Phytophthora Cinnamomi: Testing and Genetic Control
}

\author{
By M. E. Miranda-Fontaíña ${ }^{1)}$, J. Fernández-LóPez ${ }^{1)}$, A. M. Vettraino ${ }^{2)}$ and A. VAnninI ${ }^{2)}$
}

(Received 23 $3^{\text {th }}$ May 2005)

\begin{abstract}
Summary
The resistance of chestnut clones to Phytophthora cinnamomi was evaluated by a soil inoculation experiment under controlled environmental conditions, as well as by excised and intact stem tests. One-year-old plants of fifty different clones were inoculated with two isolates of Phytophthora cinnamomi and evaluated fourteen weeks after inoculation. There were significant differences among clones for all root and collar rot variables. There were significant differences for isolates of $P$. cinnamomi but only for the collar rot variables. A total of $84 \%$ of plants grown in infested soil showed symptoms of root rot but only $50 \%$ of the plants with root rot, showed also had collar rot. The roots of resistant clones were able to confine the colonization, in roots and from roots to collar. Percentage circumference of collar rot was the best indicator or descriptor of sensitivity, a $50 \%$ of clones were resistant or highly resistant clones, with respectively less than $20 \%$ and than $10 \%$ circumference of collar rot. Percentage of survival of plants is not sufficient to indicate resistance to the pathogen, as mortality may be affected by environmental conditions or by other pathogens. The clonal heritability of collar rot variables ranged between 0.54 and 0.71 . The plants grown on inoculated soil showed a reduction in growth. The phenotypic and genotypic correlations between soil infestation characteristics and the length of necrosis in both intact and excised stem tests were positive and highly significant and indicated similar resistance rankings of the clones.
\end{abstract}

Key words: Chestnut, ink disease resistance, heritability, phenotypic and genotypic correlations, root collar rot, correlation stem test.

\section{Introduction}

Phytophthora cinnamomi is an introduced pathogen associated with the mortality in European chestnut trees (Castanea sativa Miller) growing on acid soils in the humid climate of northwestern Spain. This fungus causes ink disease, characterized by root and collar rot, usually followed by death of the trees. Clonal forestry for wood production has been promoted in the Atlantic coastal area of Galicia (NW Spain), with Euroasiatic hybrid clones, mainly Castanea crenata x $C$. sativa. The resistance of these hybrids to Phytophthora sp. is usually higher than that of Castanea sativa, but there is variability among different inter-specific hybrid genotypes (VIEITEZ, 1960; SCHAD et al., 1952).

\footnotetext{
1) Centro de Investigacións Forestais e Ambientais de Lourizán. Departamento de Producción Forestal. Xunta de Galicia. Apdo 127, 36080. Pontevedra, Spain. E-mail: memiranda.cifal@ siam-cma.org

2) Department of Plant Protection, University of Studies of Tuscia, Via S. Camillo de Lellis, 01100 Viterbo, Italy.
}

Chestnut hybrid clone forest reproduction material for commercial use in Spain must be approved as belonging to qualified or controlled categories, and its value must be demonstrated according to the requirements outlined in Directive 1999/105/EC (EUROPEAN COUNCIL, 1999) and RD 289/2003 (Boletin Oficial DEL Estado, 2003). For successful wood production in Atlantic areas, stem quality and growth as well as a certain level of resistance to Phytophthora $s p$. are used as selection criteria. While the first two traits can be assessed in field trials, evaluation of resistance in terms of survival is not straightforward, as it is difficult to differentiate the different factors related to survival in the field.

Different methods have been developed for screening the resistance of chestnut trees to Phytophthora sp. by using either intact seedlings (SANTINI et al., 2003; VETTRAINO et al., 2001a) or excised stems from seedlings or clones (FERNÁNDEZ-LóPEZ et al., 2001; SALESSES et al., 1993b; Ramos Guedes-Lafargue and SAlEsses, 1998; VETTRAINO et al., 2001b). The variable used in intact or excised stem inoculation tests is the length of lesion after inoculation (SALESSES et al., 1993b; RAMOs GuedESLAFARGUE and SALESSES, 1998; FERNÁNDEZ-LóPEZ et al., 2001; SANTINI et al., 2003; VETTRAino et al., 2001a, $2001 b)$. The variables used in the soil infestation test are "health status of the plants (scale of $0-4$ )" and percentage of necrotized roots after carrying out a soil infestation test (VETTRAINO et al., 2001b; SANTINI et al., 2003). Other qualitative and quantitative characters were assessed by VETTRAINO et al. (2001a), such as growth in height, number of leaves, dry weight, length of the stem and root necroses, crown condition and mortality.

Excised stem inoculation is the main method used to test the resistance of chestnut clones to Phytophthora cinnamomi, but this method is criticized because the results have not been shown to be clearly correlated with the results obtained in the soil inoculation test. Studies with species such as oak (RoBIN and DESPREZLoustau, 1998, 2001) and Eucalyptus (TIPPET et al., 1985) have shown that the stem and root inoculation are closely correlated in terms of relative resistance rankings.

The overall aim of the present study was to select clones with high levels of resistance to Phytophthora cinnamomi, which are able to survive on infected soils and therefore can be recommended as forest reproduction materials. The specific aims were: 1) to find useful indicator variables for screening resistant clones in a soil inoculation experiment; 2) to assess the resistance of chestnut clones; 3 ) to compare the rankings of resistance of chestnut clones resulting from the soil infestation test and excised and intact stem tests. 


\section{Materials and Methods}

\section{Plant material}

Fifty chestnut clones were selected in field trials by growth and crown form (FERNÁNDEZ-LóPEZ, 1996) and their genealogical origin determined using diagnostic isozyme loci of chestnut species (FERNÁNDEZ-LóPEZ, 1996): 44 clones are hybrids between Castanea crenata Sieb. et Zucc. x C. sativa Mill., one clone is a hybrid between Castanea mollissima Blume x C. sativa Mill. (URQUIJO, 1956; VIEITEZ, 1960) (clone 7521), four clones belong to the species Castanea sativa Mill. (clones 3205, 130, 90.042 and MARA) and one is a Castanea crenata Sieb. et Zucc. clone (2091). The French hybrid clone (CA15) (SAlesses et al., 1993a, 1993b) and the Spanish hybrid clones (111 and 2073) (FERNÁNDEZ-LÓPEZ et al., 2001) were used as resistant controls. The Spanish hybrid clones (110 and 125) were used as less resistant controls (FERNÁNDEZ-LÓPEZ et al., 2001).

The chestnut clones were propagated from cuttings during June and July 2002 and planted in plastic pots (4L) in February 2003. The plants were grown in a greenhouse at $23 \pm 3{ }^{\circ} \mathrm{C}$ in a mixed substrate $(50 \%$ perlite, $25 \%$ peat and $25 \%$ composted sterilized pine bark) fertilized with Osmocote plus. Plants of mean height $41.03 \pm 21.8 \mathrm{~cm}$ and mean diameter $5.69 \pm 1.87 \mathrm{~mm}$ were used for the test at the end of May 2003.

\section{Isolation, identification and culture of Phytophthora cinnamomi}

Soil samples containing diseased chestnut roots were collected at two chestnut sites on the coast of Galicia (northwest Spain): the nursery of the Centro de Investigacións Forestais e Ambientais de Lourizán (L) and the Sigrás orchard (S). Two isolates of Phytophthora cinnamomi were obtained and identified as belonging to mating type A2 (VETTRAINo et al., 2001, 2005). The isolates designated $P$. cinnamomi Lourizán (PcL) and $P$. cinnamomi Sigrás (PcS), were maintained on carrotagar (CA) in Petri-plates at $20^{\circ} \mathrm{C}$ in darkness (BRASIER, 1969), and subcultured at 4-week intervals (VETTRAINO et al., 2001). The isolates were repassaged through chestnut micropropagated plants four weeks prior to the test as a precautionary measure against loss of pathogenicity through continuous subculturing (ERWIN and RIBEIRO, 1996; HUBERLI et al., 2001). The age of culture of both isolates was therefore the same.

Phytophthora inocula were prepared for soil infestation by growing isolates on sterilized millet seeds: $100 \mathrm{~g}$ sterilized millet seeds were placed in a jar and then moistened with $200 \mathrm{ml}$ carrot juice (200 gr carrot on $800 \mathrm{ml}$ distilled water) as described by VETTRAINO et al. (2001). The jars of millet were divided into three groups for three treatments: PcL (for inoculation with $P$. cinnamomi Lourizán), PcS (for inoculation with $P$. cinnamomi Sigrás) and Control (without inoculum). For preparing $\mathrm{PcL}$ and $\mathrm{PcS}$, half a Petri-plate $(9 \mathrm{~cm})$ of inoculum was cut and added, mycelia side down, to the millet seeds. To prepare the control treatment, half a Petri-plate of carrot-agar with no inoculum was added to the millet. The jars of millet with isolates were incubated during three weeks at $24 \pm 1^{\circ} \mathrm{C}$ in the dark in a growth chamber
Three plants per isolate were selected to reisolate $P$. cinnamomi at the end of experiment, as described by THEMANN and WERRES (1998, www.bba.de/phytoph diagn_r.htm).

\section{Experiment design}

The trial consisted of five blocks or plots (1-5) with three treatments per plot/block (control (Cont), P. cinnamomi Lourizán (PcL) and P. cinnamomi Sigras (PcS)). Each of the fifteen block-treatment combinations was a complete randomized design including one plant for each one of 50 clones. Fifteen plants per clone were initially used for the test, so there were 5 replicates per clone per treatment. Some plants died during preparation of the test, thus, the mean number of plants per clone and treatment was 4,56 and the design of the test was unbalanced. A total of 440 plants were finally tested for the presence of $P$. cinnamomi coming from inoculation with $\mathrm{PcL}$ and $\mathrm{PcS}$ isolations, at the end of the experiment.

In addition to the soil inoculation experiment, two tests were carried out: the first experiment consisted on the inoculation on the apex of excised stem of fifty one chestnut clones (33 common clones to soil inoculation test), using three treatments (control (without inoculum) and two isolates of P. cinnamomi (PcL and PcS)), in controlled environmental conditions in greenhouse and with stems collected in June (spring) and October (autumn) (MIRANDA-FONTAÍÑA et al., 2007). The second trial consisted on the inoculation on the apex of intact plant stem of thirty clones (20 common clones to soil inoculation test), using two treatments (control (without inoculum) and one isolate of $P$. cinnamomi (PcL), in June (Miranda-Fontaíña and Fernández-LóPEZ, 2005). In these tests, the length of lesions produced after 14 and 21 days was used as an indicator of $P$. cinnamomi resistance; also survival after 14, 21 and 28 days was recorded in the second trial. Analyses of variance were applied to the results to study the effects of genotype, the isolates of $P$. cinnamomi and the interaction between genotype and isolates, in the first trial; and to study the effects of genotype, the treatment (control and isolate) and the interaction between genotype and treatment, in the first and second trials. The length of necrosis after 14 days in autumn showed values that ranged between $1.7 \mathrm{~cm}$ and $8.8 \mathrm{~cm}$ from the most resistant to the most susceptible clone, in excised stem test. A continuous range of resistance-susceptibility levels among clones was obtained in these tests. The rankings of resistance to Phytophthora cinnamomi obtained in these tests were compared with the rankings obtained in the soil inoculation test.

\section{Inoculation}

The plants were watered to field capacity by subirrigation prior to the test and inoculated at the end of May 2003. The inoculum was added at a rate of $20 \mathrm{ml}$ inoculum per $1000 \mathrm{ml}$ soil mix (VETTRAINO et al., 2001) (60 ml per pot). Four small holes were made in the substrate close to the pot, taking care to avoid damaging the roots. The inoculum was placed in the holes and covered with substrate. Controls were inoculated with sterile millet. 
The pots with the soil mixture, plants and inoculum were flooded for 24 hours (VETTRAINo et al., 2001) by placing the pots in larger buckets to maintain the water level 1-2 $\mathrm{cm}$ above the surface of the soil, as described by BRowne and Mircetich (1988). During the following weeks the plants were maintained in a controlledenvironment greenhouse (temperature $23 \pm 3^{\circ} \mathrm{C}$, high humidity supplied with a fog-press system) and subirrigated for $1 \mathrm{~h}$ every other day. Fourteen weeks after inoculation, plants were examined to evaluate their resistance to the pathogen.

\section{Variables}

The variables assessed in each plant during and at the end of the test were initially based on those proposed by Browne and Mircetich (1993), Vettraino et al. (2001) and VANNINI and VETTRAINO (2002):

Survival of plants: The percentages were calculated from plants died during the test. The plants that died before and immediately after inoculation and flooding (during the first days of the test) was recorded and the plants were examined for the presence of rot symptoms.

Visual symptoms of root or collar rot in plants associated with Phytophthora infection. To verify in each plant, the presence of brown to dark brown areas in collar and roots, portions of bark were removed with a scalpel. The assessment of lesions is based on their frequency, level and size:

- Root rot percentage, Collar rot percentage: The percentages were calculated from plants with presence (1) or non- presence (0) and were calculated separately for clones and for treatments.

- Level of root rot and scale of resistance: The level of lesions was assessed in each plant on the basis of 6 categories; each assigned a value of between 0 and 5, allowing quantitative evaluation of a qualitative character.

- No visible symptoms. May be resistant to penetration. Value 0.

- Less than 10 small localized lesions, of length less than $0.5 \mathrm{~cm}$. These small lesions only occur in a few large or small roots. Value 1.

- Confined lesions of length between 0.5 and $1 \mathrm{~cm}$. These lesions only occur in a few large or small roots. Value 2.
- Localized lesions of length less than $2 \mathrm{~cm}$. These lesions only occur in a few large or small roots. Value 3.

- Large roots with few lesions of less than $2.5 \mathrm{~cm}$ and with little lesions. Value 4

- All large and small roots have abundant expanding lesions of more than $2.5 \mathrm{~cm}$ along with many little small lesions in all large roots. Value 5.

A scale of resistance was defined on the basis of the 6 categories described, allowing classification of the clones by the mean value obtained (Table 1).

- Percentage Circumference of collar rot: This symptom was assessed by visual estimation of the lateral extent of lesion around the circumference of the collar in each plant, as between 0 (healthy) and 100 (100\% circumference of collar rot). A scale of resistance-susceptibility was then defined on the basis of the range of percentage circumference of collar rot (allowing classification of the clones by the mean value obtained (Table 1)). This variable shows the capacity of plant of confining the pathogen in roots or the pathogen spread widely to stem.

- Collar rot length: the vertical length of collar rot lesion on the stem was measured with a digital caliper, to the nearest $\mathrm{mm}$. A scale of resistance was defined (Table 1) on the basis of the length of the lesions in $\mathrm{cm}$, allowing classification of the clones according to the mean value obtained. This variable shows the capacity of plant of confining the pathogen in roots or the pathogen spread widely to stem.

Other non-specific variables:

- Leaf persistence from the collar to the apex at the end of the test. Visual scale, from 0 to 10 , based on the percentage of stem with leaves.

- Height growth, collar growth of plants measured during the test: height in $\mathrm{cm}$, diameter in $\mathrm{mm}$.

- Dry weight aboveground portion, dry weight underground portion of each plant in g, after drying 24 hours at $80^{\circ} \mathrm{C}$.

\section{Data Analysis}

Analyses of variance were applied to the results to study the effects of genotype, the treatment (i.e. experimental inoculation with isolates of $P$. cinnamomi) and

Table 1. - Level of resistance-susceptibility and classification of clones according to the mean clonal value obtained in Student-Newman-Keuls test of level of root rot, percentage circumference of collar rot and collar rot length.

\begin{tabular}{|c|c|c|c|}
\hline \multirow{2}{*}{$\begin{array}{l}\text { Level of } \\
\text { Resistance-Susceptibility }\end{array}$} & Roots & Collar & Collar \\
\hline & \multicolumn{3}{|c|}{ Mean clonal Value (Student-Newman-Keuls test) } \\
\hline $\begin{array}{l}\text { To spreading of the } \\
\text { pathogen in roots or } \\
\text { collar: }\end{array}$ & Root rot & $\begin{array}{c}\text { Range of Percentage } \\
\text { Circumference of } \\
\text { collar rot }\end{array}$ & $\begin{array}{l}\text { Collar rot length } \\
\text { In } \mathrm{cm}\end{array}$ \\
\hline Highly Resistant & 0 to $<1$ & 0 to $<10$ & $<0.5$ \\
\hline Resistant & $\geq 1$ to $<2$ & $\geq 10$ to $<20$ & $\geq 0.5$ to $<1$ \\
\hline Partially resistant & $\geq 2$ to $<3$ & $\geq 20$ to $<30$ & $\geq 1$ to $<2$ \\
\hline Susceptible & $\geq 3$ to $<4$ & $\geq 30$ to $<50$ & $\geq 2$ to $<3$ \\
\hline Highly susceptible & $\geq 4$ to 5 & $\geq 50$ & $\geq 3$ \\
\hline
\end{tabular}


the interaction between genotype and treatments, using the following mixed model:

$$
\mathrm{X}_{\mathrm{ijk}}=\mu+\mathrm{C}_{\mathrm{i}}+\mathrm{T}_{\mathrm{j}}+\mathrm{C}^{*} \mathrm{~T}_{\mathrm{ij}}+\varepsilon_{\mathrm{k}(\mathrm{ij})}
$$

Where: C: Clone $(i=50), T$ : Treatment $(j=3)$ or Isolate $(\mathrm{j}=2), \mathrm{C}^{*} \mathrm{~T}$ : Interaction between Clones and Treatments or Isolates, $\varepsilon$ : Residual effect.

Treatment was considered as a fixed factor and clone was considered as a random factor.

To evaluate the efficiency of experimental inoculation with $P$. cinnamomi, an initial analysis was carried out with the three treatments (including the control, PcL and $\mathrm{PcS}$ ). To estimate clonal variability in resistance to P. cinnamomi and differences between Phytophthora cinnamomi isolates, the same analysis of variance was applied, but excluding data from the control treatment.

A Student-Newman-Keuls test was used to obtain groups of homogeneous treatments and clones. To study the distribution of the variability among different factors, variance components were calculated using the mean square values and corresponding expected mean square coefficients generated from PROC GLM, RANDOM/test option (SAS Inc., 1989). For all analyses, the sources of variation were considered significant at $\alpha=5 \%$.

Clonal heritabilities $\left(\mathrm{H}^{2}{ }_{\mathrm{c}}\right)$ were calculated as:

$$
H_{C}^{2}=\frac{\sigma_{C}^{2}}{\left(\sigma_{C}^{2}+\frac{\sigma^{2}{ }_{C T}}{T}+\frac{\sigma^{2}{ }_{e}}{R T}\right)}
$$

Where $\sigma^{2}{ }_{\mathrm{C}}, \sigma_{\mathrm{C} * \mathrm{~T}}^{2}, \sigma_{\mathrm{e}}^{2}$ are variances due to clones, interaction of clones and treatments and error variance, and $\mathrm{R}$ and $\mathrm{T}$ are the number of replicates and treatments.

The standard errors of clonal heritabilities were obtained by the formula given by FALCONER (1989):

$$
S\left(H^{2}{ }_{C}\right)=\frac{2\left[1+H^{2}{ }_{C}(\mathrm{n}-1)\right]^{2}\left(1-H^{2}{ }^{2}\right)^{2}}{(\mathrm{n}(\mathrm{n}-1)(\mathrm{N}-1))}
$$

Where $\mathrm{n}$ and $\mathrm{N}$ are the mean number of individuals per clone and mean number of clones, respectively.
Phenotypic and Genotypic correlations: Pearson's phenotypic correlation coefficients were calculated to evaluate the strength of the relationship between traits in the soil infestation test as well as between traits from soil infestation test and the length of necrosis from excised and intact stem tests (PROC CORR).

Type A genotypic correlations were estimated as described by BRIDGEWATER (1992) to study the correlations of the different traits measured in the same plants. The genetic correlation between two traits ( $\mathrm{x}$ and y) $\left(r_{\text {gAxy }}\right)$ is obtained by dividing the genetic covariance $\left(\operatorname{Cov}_{\text {gxy }}\right)$ by the product of the genetic standard deviations:

$$
r_{g A x y}=\frac{\operatorname{Cov}_{\mathrm{gxy}}}{\left(\sigma_{\mathrm{gx}}^{2} \sigma_{\mathrm{gy}}^{2}\right)^{1 / 2}}
$$

The standard deviations were obtained by taking the square root of the product of the genetic variances of the two traits.

Type B Genotypic correlations were estimated between pairs of traits from the soil infestation test and from the excised and intact stem tests to compare the rankings of resistance. Type $\mathrm{B}$ genetic correlations were estimated using the method of BURDON (1977):

$$
r_{g B}=\frac{r_{s e}}{\left(H_{C s} H_{C e}\right)}
$$

Where $r_{\mathrm{se}}$ is the phenotypic correlation between genetic group means in the soil test "s" and stem test "e", and $\mathrm{H}_{\mathrm{Cs}}$ and $\mathrm{H}_{\mathrm{Ce}}$ are square-roots of heritabilities of the genetic group means in soil test "s" and stem test "e", respectively.

\section{Results and Discussion}

Effect of isolate of P. cinnamomi and genotype on root and collar rot

No symptoms associated with Phytophthora were observed in the roots or collar of the control plants (no treatment). A total of $84 \%$ of plants grown in infested soil showed symptoms of root rot (Table 2). Figure 1 shows chestnut plant with collar and root rot.

Table 2. - Influence of clone, isolate of P. cinnamomi and clone-isolate interaction on collar and root rot. Mean squares with significant levels of the analysis of variance. Mean values of both the most resistant (Resist.) and the most sensible (Sens.) clone, overall mean values with their standard deviations (SD) and Clonal heritabilities $\left(\mathrm{H}^{2}{ }_{\mathrm{c}}\right)$ with their standard errors (S).

\begin{tabular}{|lccccc|}
\hline Source of variation & $\begin{array}{c}\text { Root rot } \\
\text { percentage }\end{array}$ & $\begin{array}{c}\text { Root rot } \\
\text { Level }\end{array}$ & $\begin{array}{c}\text { Collar rot } \\
\text { percentage }\end{array}$ & $\begin{array}{c}\text { Percentage } \\
\text { circumference } \\
\text { of collar rot }\end{array}$ & $\begin{array}{c}\text { Collar rot } \\
\text { Length (cm) }\end{array}$ \\
\hline Clone & $0.18^{*}$ & $6.16^{* * *}$ & $0.55^{* * *}$ & $6.15^{* * *}$ & $11.60^{* *}$ \\
Isolate & $0.25 \mathrm{~ns}$ & $8.85 \mathrm{~ns}$ & $8.75^{* * *}$ & $76.64^{* * *}$ & $85.33^{* * *}$ \\
Clone* Isolate & $0.09 \mathrm{~ns}$ & $2.31 \mathrm{~ns}$ & $0.17 \mathrm{~ns}$ & $1.78 \mathrm{~ns}$ & $5.31^{*}$ \\
Resist.- Sens. & $50.0-100$ & $1.10-4.33$ & $0.00-100$ & $0.00-62.8$ & $0.00-4.50$ \\
\hline Mean $\pm \mathrm{SD}$ & $84.23 \pm 35.96$ & $2.50 \pm 1.58$ & $44.86 \pm 49.58$ & $21.3 \pm 29.7$ & $1.11 \pm 2.14$ \\
\hline $\mathrm{H}^{2}{ }^{ \pm} \mathrm{S}$ & $0.39 \pm 0.05$ & $0.64 \pm 0.05$ & $0.65 \pm 0.04$ & $0.71 \pm 0.04$ & $0.54 \pm 0.05$ \\
\hline
\end{tabular}

$\mathrm{ns}=\mathrm{P}>0.05 ; *=\mathrm{P}>0.01 ; * *=\mathrm{P}<0.01 ; * * *=\mathrm{P}<0.001$. 


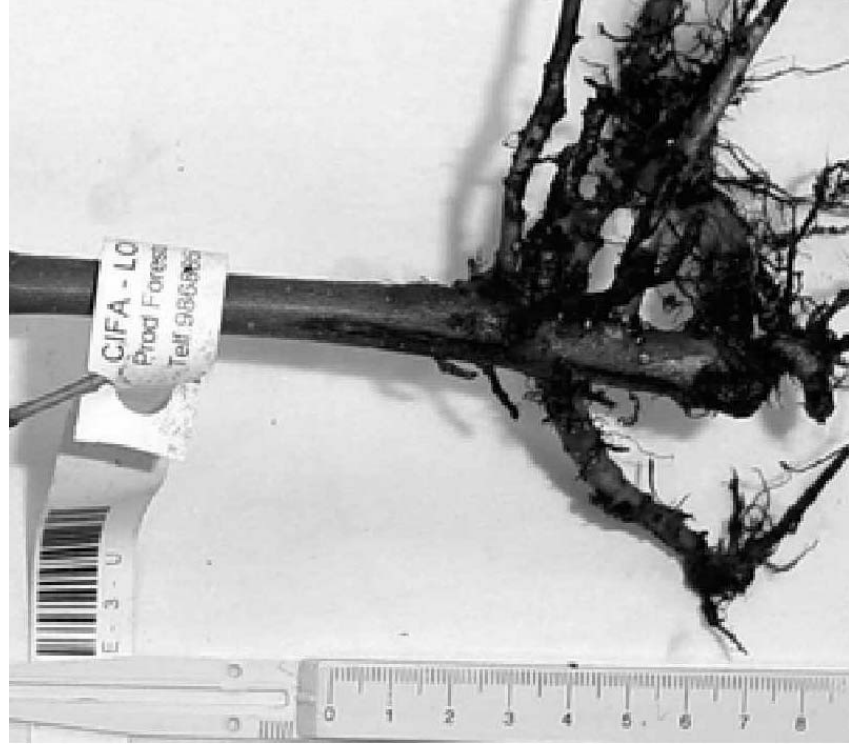

Figure 1. - Chestnut plant with collar and root rot.

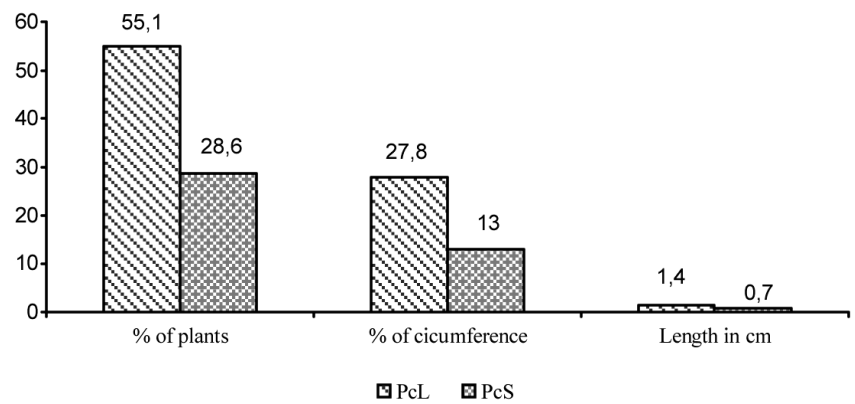

Figure 2. - Effect of Treatment, P. cinnamomi Lourizán (PcL) and P. cinnamomi Sigras (PcS), on percentage of plants with collar root (\% of plants), percentage circumference of collar rot (\% of circumference) and length of collar rot in centimetres (Length in $\mathrm{cm}$ ).

Analyses of variance revealed significant differences for isolates of $P$. cinnamomi but only for the collar rot variables (Table 2). Plants grown in PcL infested soil showed a higher (by a factor of two) percentage of collar rot, percentage circumference of collar rot and length of collar rot than plants grown with $\mathrm{PcS}$ isolate (Figure 2). The higher susceptibility to collar rot in plants growing on soil inoculated with the PcL isolate confirms the higher aggressiveness of this isolate, as observed in excised stem tests (MirANDA-FonTAÎ́NA et al., 2007).

There was no significant interaction between isolates and clones, indicating that there was no clone specificity to these isolates of $P$. cinnamomi. The lack of clone specificity for the two isolates of $P$. cinnamomi shown in the present study must be confirmed with more isolates, as cultivars specificity has been shown among isolates of P. cactorum (ALDWINCKLE et al., 1975).

Analyses of variance showed significant differences among clones for all root and collar rot variables (Table $2)$. Plants with root rot were observed within all clones, but the number of plants affected varied between 50 and $100 \%$ among clones (Figure 3). On the basis of the level of root rot, the group of clones were classified as follows

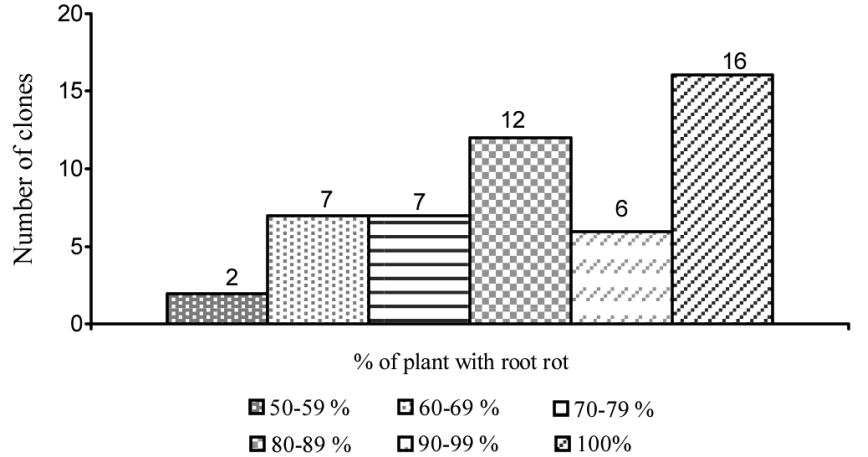

Figure 3. - Number of clones grouped according to the observed percentage of plants showing root rot within the individual clones.

(Table 3): one third of clones (16 clones) were classified as resistant to spreading of pathogen in roots, most of these plants showed confined, small lesions in a few roots. Forty two percent of the clones (21 clones) were partially resistant and showed localized lesions of 0.5 to $2 \mathrm{~cm}$ in some large and small roots. One fifth of the clones (10 clones) were susceptible, showing large and small lesions in all large roots. Only three clones were highly susceptible to spreading of pathogen in roots, showing abundant expanding lesions of more than 2.5 $\mathrm{cm}$ accompanied by many small lesions in all large roots. Two of these highly susceptible clones were hybrid clones (125 and 3U) and one was the C. sativa clone (3205) (Table 3).

Considering all clones, some $44 \%$ of plants grown in infested soil showed collar rot (Table 2). Therefore only $50 \%$ of the plants with root rot, showed also had collar rot. In only one clone none of the 10 plants showed symptoms of collar rot. The remaining 49 clones had collar rot, but the number of plants of each clone showing symptoms varied, ranging between $10 \%$ and $100 \%$ (Figure 4). For most clones, collar rot was observed in $50 \%$ of the plants, in one clone (clone 90.025) collar rot was observed in all of the plants and in the no resistant control clone (125) only one plant didn't show collar rot. In two Castanea sativa clones, 3205 and Mara, respectively $80 \%$ and $50 \%$ of the plants showed symptoms of collar root.

The percentage circumference of collar rot varied among clones, ranging between 0 and $62 \%$ of circumference depending on the clone (Table 3). A quarter of clones were classified as highly resistant to spreading of lesion from roots to collar, less than $10 \%$ of collar circumference was rotten (Table 3), these clones had a high aptitude for to confine in roots the colonization by $P$. cinnamomi. Another quarter of clones was resistant (less than $20 \%$ circumference of collar rot). Eleven clones were partially resistant (20-30\% circumference of collar rot). Nine clones were classified as susceptible, with collar rot in more than one third of circumference (30-50\% of circumference), clone 3205 (C. sativa) showed more than $46 \%$ circumference of collar rot. In another group of five clones more than of $50 \%$ of collar circumference was rotten. One of these clones was the above-mentioned clone 90.025. Only one clone (L315) showed more 
Table 3. - Classification of clones according to the mean clonal value obtained in Student-Newman-Keuls test (SNK test) of level of root rot, percentage circumference of collar rot, collar rot length and percentage of survival with the level of resistance-susceptibility (R-S).

\begin{tabular}{|c|c|c|c|c|c|c|c|c|c|c|}
\hline \multicolumn{3}{|c|}{ Level of Root rot } & \multicolumn{3}{|c|}{$\begin{array}{l}\text { Percentage circumference of } \\
\text { collar rot }\end{array}$} & \multicolumn{3}{|c|}{ Collar rot Length } & \multicolumn{2}{|c|}{$\begin{array}{c}\text { Percentage } \\
\text { Survival }\end{array}$} \\
\hline Clone & SNK test & $\begin{array}{l}\text { Level } \\
\text { R-S }\end{array}$ & Clone & SNK test & $\begin{array}{l}\text { Level } \\
\text { R-S }\end{array}$ & Clone & $\begin{array}{l}\text { SNK } \\
\text { test }\end{array}$ & $\begin{array}{l}\text { Level } \\
\text { R-S }\end{array}$ & Clone & SNK test \\
\hline 125 & $4.3 \mathrm{a}^{(1)}$ & $\mathrm{HS}$ & $\mathrm{L} 315$ & $62.8 \mathrm{a}$ & HS & 2003 & $4.5 \mathrm{a}$ & HS & 90.025 & $33.3 \mathrm{e}$ \\
\hline $3205^{*}$ & $4.1 \mathrm{ab}$ & HS & 90.025 & $53.3 \mathrm{ab}$ & HS & $3205^{*}$ & $4.4 \mathrm{ab}$ & HS & 2034 & $55.6 \mathrm{de}$ \\
\hline $3 \mathrm{U}$ & $4.0 \mathrm{abc}$ & HS & $3 \mathrm{U}$ & $52.0 \mathrm{abc}$ & HS & 90.025 & $3.6 \mathrm{abc}$ & HS & $503 \mathrm{U}$ & $55.6 \mathrm{de}$ \\
\hline L315 & $3.8 \mathrm{abcd}$ & $\mathrm{S}$ & T13 & $50.0 \mathrm{abcd}$ & HS & 2034 & $3.4 \mathrm{abc}$ & HS & 3201 & $57.1 \mathrm{cde}$ \\
\hline RH13 & $3.7 \mathrm{abcd}$ & $\mathrm{S}$ & 2003 & $50.0 \mathrm{abcd}$ & HS & $3 \mathrm{U}$ & $2.5 \mathrm{abc}$ & $\mathrm{S}$ & L315 & $57.1 \mathrm{cde}$ \\
\hline T13 & $3.7 \mathrm{abcd}$ & $\mathrm{S}$ & 2034 & 48.8 abcde & $\mathrm{S}$ & $\mathrm{T} 13$ & $2.3 \mathrm{abc}$ & $\mathrm{S}$ & H13CS & 60.0 bcde \\
\hline 2003 & $3.6 \mathrm{abcd}$ & $\mathrm{S}$ & 125 & 46.6 abcde & $\mathrm{S}$ & $90.044 \mathrm{U}$ & $2.1 \mathrm{abc}$ & $\mathrm{S}$ & 110 & $66.7 \mathrm{abcd}$ \\
\hline $503 \mathrm{U}$ & $3.5 \mathrm{abcd}$ & $\mathrm{S}$ & $3205^{*}$ & 46.0 abcde & $\mathrm{S}$ & 125 & $2.0 \mathrm{abc}$ & $\mathrm{S}$ & 2003 & $75.0 \mathrm{abcd}$ \\
\hline $7810 \mathrm{U}$ & $3.5 \mathrm{abcd}$ & $\mathrm{S}$ & 3201 & 45.7 abcde & $\mathrm{S}$ & MARA* & $1.9 \mathrm{abc}$ & PR & $90.044 \mathrm{U}$ & 77.8 abcd \\
\hline MARA* & $3.1 \mathrm{abcd}$ & $\mathrm{S}$ & 2692 & 34.0 abcde & $\mathrm{S}$ & 3201 & $1.8 \mathrm{abc}$ & PR & 2765 & $85.7 \mathrm{abcd}$ \\
\hline 2034 & $3.1 \mathrm{abcd}$ & $\mathrm{S}$ & MARA* & $33.3 \mathrm{abcde}$ & $\mathrm{S}$ & 2646 & $1.7 \mathrm{abc}$ & PR & HS & $85.7 \mathrm{abcd}$ \\
\hline $90.044 \mathrm{U}$ & $3.0 \mathrm{abcd}$ & S & 110 & 33.3 abcd & $S$ & 2671 & $1.7 \mathrm{abc}$ & PR & 2671 & 87.5 abcd \\
\hline $\mathrm{H} 13 \mathrm{CS}$ & $3.0 \mathrm{abcd}$ & $\mathrm{S}$ & 2671 & 32.5 abcde & $\mathrm{S}$ & L315 & $1.6 \mathrm{abc}$ & PR & 125 & 88.9 abc \\
\hline 136 & $2.9 \mathrm{abcd}$ & PR & 133 & 30.0 abcde & $\mathrm{S}$ & 103 & $1.5 \mathrm{abc}$ & PR & $\mathrm{X}$ & $88.9 \mathrm{ab}$ \\
\hline 2692 & $2.9 \mathrm{abcd}$ & PR & $503 \mathrm{U}$ & 28.8 abcde & PR & 2692 & $1.5 \mathrm{abc}$ & PR & 136 & $90.0 \mathrm{ab}$ \\
\hline 3201 & $2.8 \mathrm{abcd}$ & PR & $760 \mathrm{U}$ & 27.5 abcde & PR & $760 \mathrm{U}$ & $1.2 \mathrm{bc}$ & PR & 90.042 & $100 \mathrm{a}$ \\
\hline 90.025 & $2.8 \mathrm{abcd}$ & PR & $7810 \mathrm{U}$ & 26.0 abcde & PR & RH13 & $1.2 \mathrm{bc}$ & PR & $7810 \mathrm{U}$ & $100 \mathrm{a}$ \\
\hline 374 & $2.8 \mathrm{abcd}$ & PR & $90.044 \mathrm{U}$ & 24.4 abcde & PR & $503 \mathrm{U}$ & $1.1 \mathrm{c}$ & PR & $70.005 \mathrm{U}$ & $100 a$ \\
\hline $88 \mathrm{U}$ & 2.8 abcd & PR & RH13 & 24.4 abcde & PR & 133 & $1.1 \mathrm{c}$ & PR & RH13 & $100 \mathrm{a}$ \\
\hline $55 \mathrm{U}$ & $2.8 \mathrm{abcd}$ & PR & 136 & 22.0 abcde & PR & 110 & $1.0 \mathrm{c}$ & PR & $55 \mathrm{U}$ & $100 \mathrm{a}$ \\
\hline 90.020 & $2.7 \mathrm{abcd}$ & PR & $\mathrm{H} 13 \mathrm{CS}$ & 22.0 abcde & PR & $88 \mathrm{U}$ & $0.9 \mathrm{c}$ & $\mathrm{R}$ & $592 \mathrm{U}$ & $100 \mathrm{a}$ \\
\hline $\mathrm{X}$ & $2.6 \mathrm{abcd}$ & PR & 103 & 20.0 abcde & PR & 16 & $0.9 \mathrm{c}$ & $\mathrm{R}$ & $502 \mathrm{U}$ & $100 \mathrm{a}$ \\
\hline $760 \mathrm{U}$ & $2.6 \mathrm{abcd}$ & PR & $88 \mathrm{U}$ & 20.0 abcde & PR & $\mathrm{H} 13 \mathrm{CS}$ & $0.9 \mathrm{c}$ & $\mathrm{R}$ & 420 & $100 \mathrm{a}$ \\
\hline 2671 & $2.6 \mathrm{abcd}$ & PR & $55 \mathrm{U}$ & 20.0 abcde & PR & 136 & $0.8 \mathrm{c}$ & $\mathrm{R}$ & $3 \mathrm{U}$ & $100 \mathrm{a}$ \\
\hline $700 \mathrm{U}$ & $2.5 \mathrm{abcd}$ & PR & $324 \mathrm{U}$ & 20.0 abcde & PR & $90.042^{*}$ & $0.8 \mathrm{c}$ & $\mathrm{R}$ & $88 \mathrm{U}$ & $100 \mathrm{a}$ \\
\hline 103 & $2.3 \mathrm{abcd}$ & PR & 2765 & 17.1 abcde & $\mathrm{R}$ & 2765 & $0.8 \mathrm{c}$ & $\mathrm{R}$ & $374 \mathrm{U}$ & $100 \mathrm{a}$ \\
\hline $592 \mathrm{U}$ & $2.3 \mathrm{abcd}$ & PR & 2646 & 16.0 bcde & $\mathrm{R}$ & $7810 \mathrm{U}$ & $0.7 \mathrm{c}$ & $\mathrm{R}$ & 374 & $100 \mathrm{a}$ \\
\hline $392 \mathrm{U}$ & $2.3 \mathrm{abcd}$ & PR & $592 \mathrm{U}$ & 16.0 bcde & $\mathrm{R}$ & $55 \mathrm{U}$ & $0.7 \mathrm{c}$ & $\mathrm{R}$ & $324 \mathrm{U}$ & $100 \mathrm{a}$ \\
\hline HS & $2.2 \mathrm{abcd}$ & PR & $70.005 \mathrm{U}$ & 16.0 bcde & $\mathrm{R}$ & 3 & $0.6 \mathrm{c}$ & $\mathrm{R}$ & 3237 & $100 \mathrm{a}$ \\
\hline 2646 & $2.2 \mathrm{abcd}$ & PR & $374 \mathrm{U}$ & 15.5 bcde & $\mathrm{R}$ & $592 \mathrm{U}$ & $0.6 \mathrm{c}$ & $\mathrm{R}$ & 3215 & $100 \mathrm{a}$ \\
\hline $70.005 \mathrm{U}$ & $2.2 \mathrm{abcd}$ & PR & 90.020 & 15.5 bcde & $\mathrm{R}$ & $700 \mathrm{U}$ & $0.5 \mathrm{c}$ & $\mathrm{R}$ & 3205 & $100 a$ \\
\hline 133 & $2.0 \mathrm{abcd}$ & PR & $90.042^{*}$ & 15.5 bcde & $\mathrm{R}$ & $111 / 1$ & $0.5 \mathrm{c}$ & $\mathrm{R}$ & 7521 & $100 \mathrm{a}$ \\
\hline 110 & $2.0 \mathrm{abcd}$ & PR & 3237 & 15.0 bcde & $\mathrm{R}$ & 90.020 & $0.5 \mathrm{c}$ & $\mathrm{R}$ & 3 & $100 \mathrm{a}$ \\
\hline 3237 & $2.0 \mathrm{abcd}$ & PR & HS & 14.2 bcde & $\mathrm{R}$ & 374 & $0.4 \mathrm{c}$ & $\mathrm{HR}$ & T13 & $100 \mathrm{a}$ \\
\hline 2073 & $1.9 \mathrm{abcd}$ & $\mathrm{R}$ & 16 & 12.0 bcde & $\mathrm{R}$ & $374 \mathrm{U}$ & $0.4 \mathrm{c}$ & HR & 2692 & $100 \mathrm{a}$ \\
\hline $90.042^{*}$ & $1.8 \mathrm{abcd}$ & $\mathrm{R}$ & 374 & 12.0 bcde & $\mathrm{R}$ & 3237 & $0.4 \mathrm{c}$ & HR & MARA & $100 \mathrm{a}$ \\
\hline 7521 & $1.7 \mathrm{abcd}$ & $\mathrm{R}$ & $700 \mathrm{U}$ & 12.0 bcde & $\mathrm{R}$ & $392 \mathrm{U}$ & $0.4 \mathrm{c}$ & HR & 2646 & $100 \mathrm{a}$ \\
\hline $502 \mathrm{U}$ & $1.7 \mathrm{abcd}$ & $\mathrm{R}$ & 3 & 10.0 bcde & $\mathrm{R}$ & $2091^{* *}$ & $0.4 \mathrm{c}$ & $\mathrm{HR}$ & 2091 & $100 \mathrm{a}$ \\
\hline CA15 & $1.7 \mathrm{abcd}$ & $\mathrm{R}$ & CA15 & 8.0 bcde & HR & $70.005 \mathrm{U}$ & $0.3 \mathrm{c}$ & HR & 2073 & $100 \mathrm{a}$ \\
\hline 16 & $1.6 \mathrm{abcd}$ & $\mathrm{R}$ & $\mathrm{X}$ & $6.6 \mathrm{bcde}$ & HR & $324 \mathrm{U}$ & $0.3 \mathrm{c}$ & HR & CA15 & $100 \mathrm{a}$ \\
\hline 420 & $1.6 \mathrm{abcd}$ & $\mathrm{R}$ & $392 \mathrm{U}$ & 6.0 bcde & HR & CA15 & $0.3 \mathrm{c}$ & HR & $392 \mathrm{U}$ & $100 \mathrm{a}$ \\
\hline $324 \mathrm{U}$ & $1.6 \mathrm{abcd}$ & $\mathrm{R}$ & 2073 & 6.0 bcde & HR & $\mathrm{X}$ & $0.3 \mathrm{c}$ & HR & 16 & $100 \mathrm{a}$ \\
\hline 2765 & $1.6 \mathrm{abcd}$ & $\mathrm{R}$ & $111 / 1$ & 6.0 bcde & $\mathrm{HR}$ & HS & $0.2 \mathrm{c}$ & $\mathrm{HR}$ & $1482 \mathrm{U}$ & $100 \mathrm{a}$ \\
\hline $374 \mathrm{U}$ & $1.5 \mathrm{abc}$ & $\mathrm{R}$ & 7521 & 5.7 bcde & HR & 2073 & $0.2 \mathrm{c}$ & HR & 90.020 & $100 a$ \\
\hline $130^{*}$ & $1.5 \mathrm{abc}$ & $\mathrm{R}$ & $502 \mathrm{U}$ & 4.4 bcde & HR & $130^{*}$ & $0.2 \mathrm{c}$ & HR & 133 & $100 \mathrm{a}$ \\
\hline 3 & $1.5 \mathrm{abc}$ & $\mathrm{R}$ & $130^{*}$ & 4.0 cde & HR & 7521 & $0.1 \mathrm{c}$ & HR & 130 & $100 a$ \\
\hline 3215 & $1.4 \mathrm{abc}$ & $\mathrm{R}$ & 3215 & $2.2 \mathrm{de}$ & $\mathrm{HR}$ & 3215 & $0.1 \mathrm{c}$ & HR & $760 \mathrm{U}$ & $100 \mathrm{a}$ \\
\hline 111/1 & $1.3 \mathrm{bc}$ & $\mathrm{R}$ & 420 & $2.0 \mathrm{de}$ & HR & $502 \mathrm{U}$ & $0.1 \mathrm{c}$ & HR & $111 / 1$ & $100 \mathrm{a}$ \\
\hline $2091 * *$ & $1.3 \mathrm{bc}$ & $\mathrm{R}$ & $2091^{* * *}$ & $2.0 \mathrm{de}$ & HR & 420 & $0.1 \mathrm{c}$ & HR & $700 \mathrm{U}$ & $100 \mathrm{a}$ \\
\hline $1482 \mathrm{U}$ & $1.1 \mathrm{c}$ & $\mathrm{R}$ & $1482 \mathrm{U}$ & $0.0 \mathrm{e}$ & HR & $1482 \mathrm{U}$ & $0.0 \mathrm{c}$ & HR & 103 & $100 \mathrm{a}$ \\
\hline
\end{tabular}

* Castanea sativa; ** Castanea crenata.

(1) Within each column, values followed by the same letter are not different at the $5 \%$ significance level.

than $60 \%$ circumference of collar rot. In this clone, $72 \%$ of plants showed symptoms of collar rot and, according to root rot level it was classified as susceptible. The highly susceptible clones (L315, 90.025, 3U, T13, 2003) were not capable of confining the pathogen and showed a high level of collar lesions.

The mean length of collar rot ranged from $0 \mathrm{~cm}$ to 4.5 $\mathrm{cm}$ (Table 3). Classification on the basis of this variable resulted in the following groups: sixteen clones $(30 \%$ of clones) with collar rot length less than $0.5 \mathrm{~cm}$ were classified as highly resistant clones. Thirteen clones were classified as resistant. Twelve clones (20\% of clones) showed collar rot length of less than two $\mathrm{cm}$ and were classified as partially resistant clones. Four clones showed collar rot length of between 2 and $3 \mathrm{~cm}$ and were classified as susceptible clones. The four highly suscepti- 


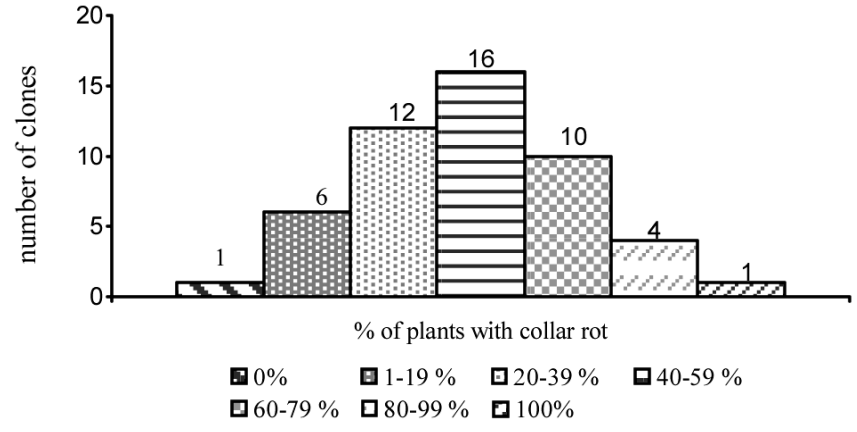

Figure 4. - Number of clones grouped according to the observed percentage of plants showing collar rot within the individual clones.

ble clones were among the eight most affected clones on the basis of the indicators of level of collar rot percentage and percentage circumference of collar rot.

The highly significant differences among clones in terms of resistance to $P$. cinnamomi observed in the soil infestation test, have also been observed in excised and intact stems tests with the same clones (MIRANDAFONTAÍÑA and FERNÁNDEZ-LÓPEZ, 2005; MIRANDAFONTAÍNA et al., 2006). In soil infestation test, in some clones confined lesions on roots were characteristic, while in other groups of clones abundant lesions all over the root system and collar were observed. CAHILL et al. (1993) have shown that the roots of a resistant line of clonal Eucalyptus (but not susceptible seedlings) were able to restrict and confine colonization by $P$. cinnamomi and found that the root infestation by $P$. cinnamomi resulted in reduced water transport, wilting and death of Eucalyptus seedlings. Clones with high percentage of collar rot and lengths of collar rot have no resistance against the pathogen and have no capacity to confine $P$. cinnamomi (clones 90.025). Percentage circumference of collar rot was the best indicator or descriptor of sensitivity.

The clonal heritability of rot root level and collar rot variables ranged between 0.54 and 0.71 (Table 2). The clonal heritabilities of length in excised stems tests ranged between 0.92 and 0.95 and in intact stems test ranged between 0.81 and 0.06 .
Genotypic correlations between collar and root rot variables were positive and ranged from 0.89 to 1 (Table 6 ). Phenotypic correlations between all root rot and collar rot variables were positive and highly significant (Table 6). The high genotypic correlations and the high heritability values indicate that resistance of chestnut to $P$. cinnamomi is under genetic control as in the resistance of Eucalyptus marginata to P. cinnamomi (STUKELY and CRANE, 1994).

\section{Effect of clone and isolate of P. cinnamomi on Survival}

Results of analysis of variance of survival (Table 4) revealed that there were significant differences among clones, between isolates of $P$. cinnamomi and for cloneisolate interaction. The plants grown in soil infested with the PcL isolate showed an overall survival rate of $73.7 \%$, and plants grown in soil infested with PcS isolate showed a survival rate of $93.5 \%$.

The clonal means of survival of plants grown in infested soil ranged from $33 \%$ to $100 \%$ among clones (Table 3 ). The clone showing the lowest rate of survival (33\%) was clone 90.025. This clone was classified as highly susceptible on the basis of the collar rot variable, but as partially resistant on the basis of the level of root rot.

Low mortality after soil inoculation has been used as an indicator of $P$. cinnamomi resistance (STUKELY and CRANE, 1994; HARRIS et al., 1983; VETTRAINO et al., 2000, 2001). The high negative phenotypic and genotypic correlations between collars rot variables and survival suggested that collar rot was the main cause of death due to Phytophthora. DAVISON et al. (1994) found that colonization by the pathogen at the small collar of one-year old Eucalyptus and pine plants is correlated with incidence of death, this may be caused by rapid invasion of $P$. cinnamomi into phloem and xylem, which may thus affect water movement through the stem.

The phenotypic correlations among survival and root rot variables were significant (Table 6 ), but the relation between root rot lesion and plant death is not completely clear because some clones with a high percentage of root rot and level of root rot survived longer than others with a low percentage of root rot. The three most sensitive clones in level of root rot showed survival rates of

Table 4. - Influence of clone, Isolates of P. cinnamomi and clone-isolate interaction on survival leaves persistence and growth. Mean squares and signification levels of the model analysis of variance (excluded control treatment), Minimum (Min.) and Maximum (Max.) clonal mean values, overall mean values with their standard deviations (SD) and clonal heritabilities $\left(\mathrm{H}^{2}{ }_{\mathrm{c}}\right)$ with their standard errors (SE).

\begin{tabular}{|lcccccc|}
\hline $\begin{array}{l}\text { Source of } \\
\text { Variation }\end{array}$ & $\begin{array}{c}\text { Survival } \\
\mathbf{( \% )}\end{array}$ & $\begin{array}{c}\text { Leaf } \\
\text { Persistence }\end{array}$ & $\begin{array}{c}\text { Height } \\
\text { Increment }\end{array}$ & $\begin{array}{c}\text { Diameter } \\
\text { Increment }\end{array}$ & $\begin{array}{c}\text { Stem } \\
\text { Dry weight } \\
497.15^{*}\end{array}$ & $\begin{array}{c}\text { Root dry } \\
\text { Weight } \\
193.95^{* *}\end{array}$ \\
Isolates & $1.99^{* *}$ & $10.11 \mathrm{~ns}$ & $13492.00^{* * *}$ & $94.06^{* * *}$ & $2251.14^{* *}$ & $618.66^{* *}$ \\
Clone*Isolates & $0.23 * * *$ & $13.95 \mathrm{~ns}$ & $606.64 \mathrm{~ns}$ & $6.42^{*}$ & $260.17^{*}$ & $78.12 \mathrm{~ns}$ \\
\hline Min. - Max. & $33.33-100$ & $2.40-9.40$ & $1.25-66.35$ & $0.37-7.84$ & $10.47-48.92$ & $10.39-29.85$ \\
\hline Mean \pm SD & $0.91 \pm 0.26$ & $6.30 \pm 3.77$ & $23.12 \pm 26.08$ & $3.61 \pm 2.41$ & $48.71 \pm 14.74$ & $19.74 \pm 8.78$ \\
\hline $\mathrm{H}^{2}{ }^{ \pm} \mathrm{SE}$ & $0.38 \pm 0.04$ & $0.51 \pm 0.05$ & $0.57 \pm 0.04$ & $0.73 \pm 0.05$ & $0.47 \pm 0.05$ & $0.59 \pm 0.05$ \\
\hline
\end{tabular}

$\mathrm{ns}=\mathrm{P}>0.05 ; *=\mathrm{P}>0.01 ; * *=\mathrm{P}<0.01 ; * * *=\mathrm{P}<0.001$. 
Table 5. - Influence of clone, treatment (Control, Pcl and PcS) clone-treatment interaction on survival, leaves persistence and growth. Mean squares and signification levels of the model analysis of variance, Minimum (Min.) and Maximun (Max.) clonal mean values.

\begin{tabular}{|lcccccc|}
\hline $\begin{array}{l}\text { Source of } \\
\text { Variation }\end{array}$ & $\begin{array}{c}\text { Survival } \\
\mathbf{( \% )}\end{array}$ & $\begin{array}{c}\text { Leaf } \\
\text { Persistence }\end{array}$ & $\begin{array}{c}\text { Height } \\
\text { Increment }\end{array}$ & $\begin{array}{c}\text { Diameter } \\
\text { Increment }\end{array}$ & $\begin{array}{c}\text { Stem } \\
\text { Dry weight }\end{array}$ & $\begin{array}{c}\text { Root dry } \\
\text { weight }\end{array}$ \\
\hline Clone & $0.14 \mathrm{~ns}$ & $31.56^{* * *}$ & $2669.69^{* * *}$ & $15.73^{* * *}$ & $587.07^{* * *}$ & $252.53^{* * *}$ \\
Treatment & $0.94^{* * *}$ & $8.54 \mathrm{~ns}$ & $7214.85^{* * *}$ & $51.63^{* * *}$ & $1189.32^{* *}$ & $418.51^{* *}$ \\
Clone* Treatment & $0.10^{* * *}$ & $11.47 \mathrm{~ns}$ & $645.03^{*}$ & $5.79^{*}$ & $247.51^{*}$ & $73.30 \mathrm{~ns}$ \\
\hline Min. - Max. & $0.42-1.00$ & $2.62-9.40$ & $1.83-68.14$ & $0.37-7.62$ & $10.47-43.15$ & $10.39-32.09$ \\
\hline
\end{tabular}

$\mathrm{ns}=\mathrm{P}>0.05 ; *=\mathrm{P}>0.01 ; * *=\mathrm{P}<0.01 ; * * *=\mathrm{P}<0.001$

$89 \%$ (125) and 100\% (3U, 3205). HÜBERLI et al. (1998, 2001) found that Eucalyptus and pine plants with large root lesions survived longer than other plants with small lesions.

Analyses of variance of all survival data (including data corresponding to the control treatment) revealed significant differences among clones, between treatments (control, PcL and PcS) and for clone-treatment interaction (Table 5). There was no significant difference between the plants grown with the PcS isolate and the control plants, (the survival rate of both was close to $93 \%$ ), but rate of survival of plants grown with the PcL isolate was significantly different from the others. The plants that did not survive within the control treatment (7\%) all died immediately after flooding during the first days of the test, and showed no symptoms of Phytophthora. The few plants that died during the first days in infested soils also showed no symptoms of collar or root rot. The plants that died both in infested soil and control soil belonged to the same group of clones.

A second similar test (unpublished data) carried out between July 2002 and May 2004 was developed with 2year-old plants of the same clones, the same isolates, but with ambient (i.e. not controlled) conditions in a glasshouse and watering only by mist (without subirrigation) and free drainage. Percentage of survival of plants in this test was $94 \%$ and the percentage of root rot was approximately $70 \%$ in two isolates, after two years. The low mortality in this last not subirrigated test, during two years, and the high mortality rate after flooding the samples in the data of the soil inoculation experiment under controlled environmental conditions, suggested that the mortality of plants was also related to excessive flooding. Browne and Mircetich (1988)

Table 6. - Genotypic (above the diagonal) and Phenotypic (below the diagonal) Pearson correlations coefficients between pairs of traits. Values of the diagonal are clonal heritabilities (in italic type). Genotypic correlations that values above 1 are treated as 1.

\begin{tabular}{|c|c|c|c|c|c|c|c|c|c|c|c|}
\hline$H_{c}^{2}$ & $\begin{array}{l}\text { Root Rot } \\
\text { Percentage }\end{array}$ & $\begin{array}{l}\text { Level of Root } \\
\text { Rot }\end{array}$ & $\begin{array}{l}\text { Collar Rot } \\
\text { Percentage }\end{array}$ & $\begin{array}{l}\text { Percentage } \\
\text { Circumference } \\
\text { Of collar rot }\end{array}$ & $\begin{array}{l}\text { Length of } \\
\text { Collar Rot }\end{array}$ & Survival & $\begin{array}{c}\text { Leaf } \\
\text { Persistence }\end{array}$ & $\begin{array}{l}\text { Diameter } \\
\text { Increment }\end{array}$ & $\begin{array}{c}\text { Height } \\
\text { Increment }\end{array}$ & $\begin{array}{c}\text { Stem } \\
\text { Dry weigh }\end{array}$ & $\begin{array}{c}\text { Root } \\
\text { Dry weigh }\end{array}$ \\
\hline $\begin{array}{c}\text { Root Rot } \\
\text { percentage }\end{array}$ & 0.39 & 1.15 & 1.25 & 1.20 & 1.27 & -0.81 & -0.83 & -0.71 & -0.16 & 0.14 & -0.43 \\
\hline $\begin{array}{l}\text { Level of } \\
\text { Root Rot }\end{array}$ & $0.77^{\star * *}$ & 0.64 & 1.15 & 1.04 & 0.94 & -0.67 & -0.56 & -0.66 & -0.04 & 0.08 & -0.47 \\
\hline $\begin{array}{l}\text { Collar Rot } \\
\text { Percentage }\end{array}$ & $0.54^{\star * *}$ & $0.72^{\star \star * *}$ & 0.65 & 1.05 & 1.01 & -1.16 & -0.57 & -0.53 & -0.16 & -0.14 & -0.48 \\
\hline $\begin{array}{l}\text { Percentage } \\
\text { circumference of } \\
\text { collar Rot }\end{array}$ & $0.55^{* * *}$ & $0.78^{\star * *}$ & $0.91^{* * *}$ & 0.71 & 0.89 & -0.74 & -0.52 & -0.46 & -0.19 & -0.09 & -0.38 \\
\hline $\begin{array}{l}\text { Length of } \\
\text { Collar Rot }\end{array}$ & $0.50^{* * *}$ & $0.67^{\star \star \star *}$ & $0.76^{\star \star \star}$ & $0.83^{\star \star \star *}$ & 0.54 & -0.68 & -0.51 & -0.34 & -0.25 & -0.06 & -0.28 \\
\hline Survival & -0.31 * & $-0.34^{*}$ & $-0.62^{\star \star \star *}$ & $-0.57^{* \star \star}$ & $-0.46^{* * *}$ & 0.38 & 0.33 & 0.49 & 0.33 & 0.30 & 0.69 \\
\hline $\begin{array}{c}\text { Leaf } \\
\text { Persistence }\end{array}$ & $-0.17 n s$ & -0.32 * & $-0.20 \mathrm{~ns}$ & $-0.26 \mathrm{~ns}$ & $-0.25 \mathrm{~ns}$ & $0.10 \mathrm{~ns}$ & 0.51 & 0.35 & -0.03 & 0.61 & 0.85 \\
\hline $\begin{array}{l}\text { Diameter } \\
\text { Increment }\end{array}$ & $-0.15 n s$ & $-0.22 \mathrm{~ns}$ & $-0.32^{*}$ & -0.31 * & $-0.23 \mathrm{~ns}$ & $0.26 \mathrm{~ns}$ & $0.36^{*}$ & 0.57 & 0.60 & 1.03 & 0.60 \\
\hline $\begin{array}{l}\text { Height } \\
\text { Increment }\end{array}$ & $-0.08 n s$ & $-0.02 \mathrm{~ns}$ & $-0.14 n s$ & $-0.18 n s$ & $-0.16 n s$ & $0.12 \mathrm{~ns}$ & $0.07 n s$ & $0.62^{\star \star * *}$ & 0.73 & 0.71 & 0.16 \\
\hline $\begin{array}{c}\text { Stem } \\
\text { Dry weigh }\end{array}$ & $0.12 \mathrm{~ns}$ & $0.09 \mathrm{~ns}$ & $-0.04 \mathrm{~ns}$ & $-0.04 \mathrm{~ns}$ & $-0.03 n s$ & $0.08 n s$ & $0.51^{\text {*** }}$ & $0.61^{\text {*** }}$ & $0.47^{\star \star * *}$ & 0.47 & 1.00 \\
\hline $\begin{array}{c}\text { Root } \\
\text { Dry weigh }\end{array}$ & $-0.09 \mathrm{~ns}$ & $-0.19 n s$ & $-0.30^{*}$ & $-0.29 *$ & $-0.22 \mathrm{~ns}$ & $0.29^{*}$ & $0.59 * * *$ & $0.48^{\star \star \star *}$ & $0.23 \mathrm{~ns}$ & $0.80^{\star * *}$ & 0.59 \\
\hline
\end{tabular}

a Pearson correlation coefficient (Phenotypic Correlation): $r$.

${ }^{\mathrm{b}}$ p-value: significance probability for testing the null hypothesis that the true correlation in the population is zero. $\mathrm{ns}=\mathrm{P}>0.05 ; *=\mathrm{P}>0.01 ; * *=\mathrm{P}<0.01 ; * * *=\mathrm{P}<0.001$. 
found that when trees are subjected to periods of frequent or prolonged soil flooding, the incidence and severity of Phytophthora root and crown rots in apple might increase greatly. Therefore in tests carried out under such conditions, survival alone was not sufficient to indicate resistance to the pathogen, as mortality may be affected by environmental conditions or by other pathogens such as Fusarium and Phytium. The development of these pathogens is favoured by excessive moisture and nitrogen fertilization, which inhibits plant maturation and thus favours disease development (EGEL, 1999). Plants that died under control treatment did not show any symptoms of collar or root rot caused by Phytophthora. Preventive measures, which include weekly application of a fungicide and avoiding excess watering, would also interfere with the development of Phytophthora.

Furthermore, STUKELY and CRANE (1994) considered that the soil inoculation test is particularly severe, so seedlings are exposed to live $P$. cinnamomi inoculum continuously for several months, and reported in a total of $80 \%$ of Eucalyptus and pine seedlings dying across all families.

The effect of $P$. cinnamomi on leaf persistence, height and diameter increment and stem and root dry weight

Some plants lost their leaves acropetal sense from the collar. Analysis of variance of leaf persistence, at the end of the test, revealed significant differences among clones, but no significant differences between isolates (Table 4) or treatments (Table 5) and for the interaction clone-treatment.

Analysis of variance of height and collar diameter increment and stem and root dry weight revealed highly

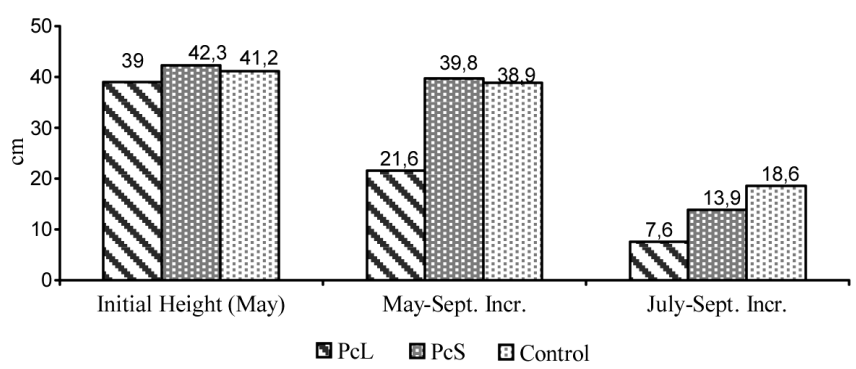

Figure 5. - Effect of treatment (P. cinnamomi Lourizán (PcL) and P. cinnamomi Sigras (PcS)) and control) on growth. Initial height in May (May), May-September height increment (MaySept. Incr.) and July-September height increment (July-Sept. Incr.) in $\mathrm{cm}$.

significant differences mainly for clones and isolates (Table 4) or treatments (Table 5). A reduction in growth of inoculated plants was observed, especially in plants grown on soil inoculated with the PcL isolate and at the second half of trial, between July and September (Figure 5). It is possible that lesions caused in roots, interfered on the absorption of water and nutrients and, as a consequence of that, the reduction on height and diameter increment of plants (Figure 5) and on stem and root dry weight. STUKELY and CRANE (1994) reported a reduction in growth in plants inoculated with $P$. cinnamomi. BENNET (1988) also observed differences in levels of infection with $P$. cinnamomi, growth reduction and mortality among clones in clonal lines of Eucalyptus.

The dry weight of inoculated plants was lower than that of control plants. The correlation between root dry weight and collar rot was negative and significant.

The correlation between leaf persistence with root rot level was negative and significant. The correlations

Table 7. - Phenotypic $\left(\mathrm{r}_{\mathrm{se}}\right)$ and genotypic correlations $\left(\mathrm{r}_{\mathrm{gse}}\right)$ between traits for soil infestation test and excised and intact stem test. Excised stem test: Length (L) of necrosis after 7(L7), 14 (L14) and 21 (L21) days in spring (sp) and autumn (au). Intact stem test: Length (L) of necrosis after 14 (L14), 21 (L21) and 28 (L28) days in spring.

\begin{tabular}{|c|c|c|c|c|c|c|}
\hline & & \multicolumn{5}{|c|}{ Soil Infestation Stem Test } \\
\hline $\begin{array}{l}\text { Excised Stem } \\
\text { Test }\end{array}$ & & $\begin{array}{c}\text { Root Rot } \\
\text { percentage }\end{array}$ & $\begin{array}{l}\text { Level of } \\
\text { Root Rot }\end{array}$ & $\begin{array}{l}\text { Collar Rot } \\
\text { Percentage }\end{array}$ & $\begin{array}{l}\text { Percentage circum- } \\
\text { ference of collar rot }\end{array}$ & $\begin{array}{l}\text { Collar Rot } \\
\text { Length }\end{array}$ \\
\hline L7sp & $\begin{array}{l}\mathbf{r}_{\text {se }} \\
\mathbf{r}_{\text {gse }}\end{array}$ & $\begin{array}{l}0.52 * * \\
0.98\end{array}$ & $\begin{array}{l}0.50^{* *} \\
0.64\end{array}$ & $\begin{array}{l}0.54^{* * *} \\
0.69\end{array}$ & $\begin{array}{l}0.51 * * \\
0.62\end{array}$ & $\begin{array}{l}0.43^{*} \\
0.60\end{array}$ \\
\hline L14sp & $\begin{array}{l}\mathbf{r}_{\text {se }} \\
\mathbf{r}_{\text {gse }}\end{array}$ & $\begin{array}{l}0.51^{* * *} \\
0.96\end{array}$ & $\begin{array}{l}0.45^{* *} \\
0.57\end{array}$ & $\begin{array}{l}0.52^{*} \\
0.66\end{array}$ & $\begin{array}{l}0.49 * * \\
0.60\end{array}$ & $\begin{array}{l}0.38^{* *} \\
0.52\end{array}$ \\
\hline L21sp & $\begin{array}{l}\mathbf{r}_{\text {se }} \\
\mathbf{r}_{\text {gse }}\end{array}$ & $\begin{array}{l}0.50 * * \\
0.96\end{array}$ & $\begin{array}{l}0.42^{*} \\
0.57\end{array}$ & $\begin{array}{l}0.48^{* *} \\
0.61\end{array}$ & $\begin{array}{l}0.47 * * \\
0.58\end{array}$ & $\begin{array}{l}0.38 * * \\
0.52\end{array}$ \\
\hline L14au & $\begin{array}{l}\mathbf{r}_{\text {se }} \\
\mathbf{r}_{\text {gse }}\end{array}$ & $\begin{array}{l}0.52 * * * \\
1.07\end{array}$ & $\begin{array}{l}0.69 * * * \\
0.96\end{array}$ & $\begin{array}{l}0.62 * * * \\
0.80\end{array}$ & $\begin{array}{l}0.62 * * * \\
0.77\end{array}$ & $\begin{array}{l}0.47^{* * *} \\
0.67\end{array}$ \\
\hline L21au & $\begin{array}{l}\mathbf{r}_{\text {se }} \\
\mathbf{r}_{\text {gse }}\end{array}$ & $\begin{array}{l}0.50^{* *} \\
0.96\end{array}$ & $\begin{array}{l}0.53 * * \\
0.69\end{array}$ & $\begin{array}{l}0.47^{* *} \\
0.61\end{array}$ & $\begin{array}{l}0.44 * * \\
0.55\end{array}$ & $\begin{array}{l}0.37 * \\
0.52\end{array}$ \\
\hline $\begin{array}{l}\text { Intact Stem } \\
\text { Test }\end{array}$ & & \multicolumn{5}{|c|}{ Soil Infestation Stem Test } \\
\hline L14sp & $\begin{array}{l}\mathbf{r}_{\text {se }} \\
\mathbf{r}_{\text {gse }}\end{array}$ & $\begin{array}{l}0.61 * * \\
1.08\end{array}$ & $\begin{array}{l}0.68 * * * \\
0.94\end{array}$ & $\begin{array}{l}0.80^{* * * *} \\
1.09\end{array}$ & $\begin{array}{l}0.73^{* * *} \\
0.96\end{array}$ & $\begin{array}{l}0.65 * * \\
0.98\end{array}$ \\
\hline L21sp & $\mathbf{r}_{\text {se }}$ & $\begin{array}{l}0.58 * * \\
1.03\end{array}$ & $\begin{array}{l}0.70 * * * \\
0.97\end{array}$ & $\begin{array}{l}0.73^{* * *} \\
1.01\end{array}$ & $\begin{array}{l}0.68 * * * \\
0.90\end{array}$ & $\begin{array}{l}0.55^{*} \\
0.83\end{array}$ \\
\hline L28sp & $\begin{array}{l}\mathbf{r}_{\text {se }} \\
\mathbf{r}_{\text {gse }}\end{array}$ & $\begin{array}{l}0.63^{* * *} \\
1.10\end{array}$ & $\begin{array}{l}0.69 * * * \\
0.95\end{array}$ & $\begin{array}{l}0.66^{* * *} \\
0.91\end{array}$ & $\begin{array}{l}0.59 * * \\
0.78\end{array}$ & $\begin{array}{l}0.57 * * \\
0.86\end{array}$ \\
\hline
\end{tabular}

$\mathrm{ns}=\mathrm{P}>0.05 ; *=\mathrm{P}>0.01 ; * *=\mathrm{P}<0.01 ; * * *=\mathrm{P}<0.001$. 
among leaf persistence with stem and root dry weight were positive and highly significant (Table 6). The lesions on roots and collar caused by $P$. cinnamomi, possibly interfered with the leaf persistence and caused a reduction of rates of photosynthesis, as a result of that, in the stem and root accumulated dry weigh.

The phenotypic correlation between collar rot and diameter increment was negative and significant (Table 6 ), but the correlations between height increment and collar and root rot variables were not significant. Root and collar rot were negatively and poorly genotypic correlated with height and diameter increment (genotypic correlation in Table 6). There was no correlation between height increment of plants and survival.

\section{Correlation between soil infestation test and excised and intact stem tests}

The phenotypic and genotypic correlations between soil infestation characteristics and the length of necrosis in both intact and excised stem tests were positive and highly significant (Table 7). The correlations between soil infestation characteristics and the length of necrosis in intact stem test were higher than correlations between soil infestation characteristics and the length of necrosis in excised stem test.

Correlations between the results of both excised and intact stem tests and the soil inoculation test indicated similar resistance rankings of the clones, thus confirming the reliability of these tests and it is therefore possible to predict the susceptibility in soil inoculation test from the results of excised and intact stem tests. Similar results were reported for apple trees by BROWNE and Mircetich (1993), who observed that mean lengths in excised and intact rootstock stems were positively correlated with mean crown rot lengths in rootstocks grown in infested soil $(r=0.59-0.79)$. Other studies have shown that stem and root inoculations are closely correlated in terms of the relative resistance rankings of species of Banksia (DIXON and THINLAY SIVASITHAMPARAM, 1984), Eucalyptus (TIPPET et al., 1985) and oak (Robin and Desprez-Loustau, 1998).

\section{Selection of variables}

Root rot percentage, root rot level, collar rot percentage, collar circumference rot and collar rot length were closely genetic correlated and the clonal heritabilities were moderate to high. Only two variables, root rot level and collar circumference rot, may therefore be evaluated, to reduce the experimental effort involved. These mentioned variables are the best indicators of $P$. cinnamomi resistance and are sufficient to estimate this character.

\section{Conclusions}

There is no clone of chestnut that is absolutely resistant to had lesions on roots but some clones are resistant to spreading of pathogen in roots and from roots to collar. There were significant differences for isolates of $P$. cinnamomi but only for the collar rot variables.

Percentage circumference of collar rot was the best indicator or descriptor of sensitivity. Percentage of sur- vival of plants is not sufficient to indicate resistance to the pathogen, as mortality may be affected by environmental conditions or by other pathogens. The plants grown on inoculated soil showed a reduction in growth.

The phenotypic and genotypic correlations between soil infestation characteristics and the length of necrosis in both intact and excised stem tests were positive and highly significant and indicated similar resistance rankings of the clones.

\section{Acknowledgements}

The present study was carried out at the Centro de Investigacións Forestais e Ambientais de Lourizán as part of "Plan de Mellora Xenética de la Xunta de Galicia (FEOGA 2000-2006)" and Project RTA04-152, (Programa Nacional de Recursos y Tecnologías Agroalimentarias). The authors express their gratitude to all staff at the nurseries of the Departamento de Producción Forestal for their help in preparing and carrying out the study; to Belén Aramburu García for her help with inoculations and evaluation of the tests, and to the reviewer of the manuscript, especially Dr. BURGi GIERLINGER and Dr. R. S. DoDD of Silvae Genetica for corrections and helpful suggestions.

\section{References}

Aldwinckle, H. S., F. J. Polach, W. T. Molin and R. C. PEARSON (1975): Pathogenicity of Phytophthora cactorum isolates from New York apple trees and other sources. Phytopathology 65: 989-994.

BENNET, I. J. (1988): Use of tissue culture techniques for the improvement of Eucalyptus marginata Donn. ex Sm. Ph. D. thesis. Murdoch University, Perth, Australia.

Boletín Oficial Del Estado (BOE) (2003): RD 289/2003 de 7 de marzo, sobre comercialización de los materiales forestales de reproducción. BOE núm. 58, 8/3/2003.

BRASIER, C. M. (1969): The effect of light and temperature on reproduction in vitro in two tropical species of Phytophthora. Transactions of the British Mycological Society 52: 105-113.

BRIDGewater, F. (1992): Mating Desings. In: Fins et al. (eds.), Handbook of Quantitative Forest Genetics. 69-95. 1992 Kluwer Academic Publishers. Netherlands.

Browne, G. T. and S. M. MirceTich (1988): Effects of flood duration on the development of Phytophthora root and crown rots of apple. Phytopathology 78(6): 846-851.

Browne, G. T. and S. M. MirceTICH (1993): Relative resistance of thirteen apple rootstocks to three species of Phytophthora. Phytopatology 83: 744-749.

BuRDON, R. D. (1977): Genetic correlation as a concept for studying genotype-environment interaction in forest tree breeding. Silvae Genetica 26: 168-175.

CAhill, D. M., I. J. BennetT and J. A. McComb (1993): Mechanisms of resistance to Phytophthora cinnamomi in clonal, micropropagated Eucalyptus marginata. Plant Pathology 42: 865-872.

Davison, E. M., M. C. Stukely, C. E. Crane and F. C. S. TAY (1994): Invasion of Phloem and Xylem of Woody Stems and Roots of Eucalyptus marginata and Pinus radiata by Phytophthora cinnamomi. Phytophatology 84 (4): $335-340$.

Dixon, K. W. and K. Thinlay Sivasithamparam (1984): Technique for rapid assessment of tolerance of Banksia spp. to root rot caused by Phytophthora cinnamomi. Plant Disease 68, 1077-80. 
EGEL, D. S. (1999): Preventing seedling diseases in the greenhouse. Purdue University Cooperative Extensio service. http://www.ces.purdue.edu/extmedia/menu.htm.

ERwin, D. C. and O. K. RIBEIRo (1996): Phytophthora Diseases Worldwide. American Phytopathological Society Press, St Paul, MN.

EuROPEAN CouncIL (1999): Directive 199/150/EC on the marketing of forest reproductive material.

FALCONER, D. S. (1989): Introduction to quantitative genetics. Third edition. Longman Scientific and Technical.

FERNÁNDEZ-LÓPEZ, J. (1996): Variabilidad isoenzimática, morfológica y selección clonal en Castanea sativa Miller Castanea crenata Sieb. et Zucc., Castanea mollissima e híbridos interespecíficos. Tesis doctoral, Univ. Polit. de Madrid.

FERNÁNDEZ-LóPEz, J., R. A. VÁZqUEZ-RUIZ-DE-OCENDA, R. DíAz-VÁzquez and S. PEREIRA-Lorenzo (2001): For. Snow Landsc. Res. Evaluation of resistance of Castanea sp. clones to Phytophthora sp. using excised chestnut shoots 76(3): 451-454.

HaRRis, J. A., F. Y. KASSABy, I. W. SMith and G. C. Marks (1983): Intra-specific variation in resistance of Phytophthora cinnamomi in Eucalyptus regnans. Aust. Plant Pathol. 12: 20-22.

Hüberli, D., G. E. St J. Hardy, I. C. Tommerup and I. J. ColquHoun (1998): Temperature changes resistance of clonal Eucalyptus marginata to Phytophthora cinnamomi. In Seventh International Congress of Plant Pathology: 2.5.4. Edinburgh.

Hüberli, D., I. C. Tommerup, M. P. Dobrowolski, M. C. CALver and G. E. St J. HARDY (2001): Phenotypic variation in a clonal lineage of two Phytophthora cinnamomi populations from Western Australia. Mycol. Res 105 (9): 1053-1064.

Miranda-FontaÍña, M. E. and J. FERnández-LóPez (2005): Variabilidad clonal de castaño híbrido en resistencia a Phytophthora cinnamomi. IV Congreso Forestal Español. Zaragoza. 26-30 Septiembre 2005. Mesa temática 2 , ponencia 4 .

Miranda-Fontaíña, M. E., Fernández-LóPez, J., VetTRAINO, A. M., VANNINI, A. 2006. Variabilidad genética en resistencia a Phytophthora cinnamomi de 51 clones de Castanea $s p$. evaluada mediante test de tallo cortado. Accepted for publication in: Investigación Agraria. Sistemas y Recursos Forestales.

Ramos Guedes-Lafargue M. and G. Salesses (1999): Ink disease resistance: some preliminary elements from the study of different crosses. Proceedings of the $2^{\text {nd }}$ Intern. Symp. on Chestnut, Bordeaux, France, 19-23 October 1998. Acta Horticulturae 464: 355-361.

Robin, C. and M. L. Desprez-Loustau (1998): Testing variability in pathogenicity of Phytophthora cinnamomi. European Journal of Plant Pathology 104, 465-75.

Robin, C., G. Capron and M. L. Desprez-Loustau (2001): Root infection by Phytophthora cinnamomi in seedlings of three oak species. Plant Pathology 50: 708-716.
Salesses, G., L. Ronco, J. E. Chauvin and J. Chapa (1993a): Amélioration génétique du chataignier, Mise au point de tests d'evaluation du comportement vis-à-vis de la maladie de léncre. Lárboriculture Fruitiere 458: $23-31$.

Salesses, G., J. Chapa and P. Chazerans (1993b): Screening and breeding for ink disease resistance. Proceedings of the International Congress on Chestnut, Spoleto, Italy, October 0-23, 545-549.

SANTini, A., G. P. BARZANTI and P. CAPERTti (2003): Susceptibility of some Mesophilic Hardwoods to Alder Phytophthora. Journal of Phytopathology 151 (7-8), 406-410.

Schad, C., G. Solignat, J. Grente and P. Venot (1952): Recherches sur le chataignier a la Station de Brive. Annales de l'amelioration des plantes III: 369-458.

Stukely, M. J. C. and C. E. CRAne (1994): Genetically based resistance of Eucalyptus marginata to Phytophthora cinnamomi. Phytopathology 84: 650-656.

ThemANn, V. K. and S. WeRRES (1998): Use of Rhododendron leaves to detect Phytophthora species in root and soil samples. Nachrichtenblatt des Deutschen Pflanzenschutzdienstes 50, 37-45.

Themann, K. and S. WerRes: Guidelines for the handling of the Rhododendron leaf test to detect Phytophthora spp. in root, soil and water samples. www.bba.de/ phytoph/diagn_r.htm

TippetT, J. T., T. C. Hill and B. L. Shearer (1985): Resistance of Eucalyptus spp. to invasion by Phytophthora cinnamomi. Australian Journal of Botany 33: 409-18.

URQUiJo, P. (1956): La regeneración del castaño. Bol. Pat. Veg. Ent. Agr. XXII, 217-232.

VANnini, A. and A. M. Vettraino (2002): Sources of resistance to Phytophthora cambivora in naturalized and cultivated proveniences of sweet chestnut in Italy and Spain. JPP. Volume 84 (3) - November 2002.

Vettraino, A. M., A. Scalise, S. Cherubini and A. VANnini (2001): Variability in resistance to Phytophthora cambivora of Castanea sativa wild population and selected cultivars in Italy and Spain. Second International IUFRO meeting on Phytophthora in forests and natural ecosystems. 30 Sept-5 Oct in Perth and Albany, Western Australia.

Vettraino, A. M, G. NAtili, N. Anselmi and A. VAnNini (2001): Recovery and pathogenicity of Phytophthora species associated with a resurgence of ink disease in Castanea sativa in Italy. Plant Pathology 50, 90-96.

Vettraino, A. M., O. Morel, C. Perlerou, S. Robin, S. DiAmandis and A. VANNINI (2005): Occurrence and distribution of Phytophthora species in European chestnut stands, and their association with Ink Disease and crown decline. European Journal of Plant Pathology 111: $169-180$ (12).

VIEITEZ, E. (1960): Obtención de castaños resistentes a la enfermedad de la tinta. Centro Regional de Enseñanzas y Experiencias Forestales de Lourizán, Pontevedra. 